\title{
POLITIKA
}

\section{SKAIDRUMO IR PRIVATUMO TAPSMAS REIKŠMINGA POLITIKOS PROBLEMA}

Prof. DR. LaURas Bielinis

Vytauto Didžiojo universiteto

Politikos moksly ir diplomatijos fakultetas

Vytautas Magnus university

Faculty of Political Science and Diplomacy

Gedimino g. 44-102, LT-44240 Kaunas

El.paštaslauras.bielinis@gmail.com

\section{Santrauka}

Straipsnyje aptariamos skaidrumo ir privatumo sąlygos šiandieninëje visuomeneje. Dabartis sukuria tokias sqlygas, sukeltas tiek radikaliu politiniu ivykiu (teroristiniai aktai), tiek ir nauju technologiniu galimybiu, kada privatumo laukas siaurëja, o asmens viešumas paverčiamas neišvengiama ir reikalinga sąlyga. Straipsnyje įvardijamos problemos, atveriančios naujas ir dar neištirtas politikos ir socialinio gyvenimo sferas, sietinas su skaidrumo didejimu ir privatumo transformacijomis. Besiklostančioje situacijoje visuomenei iškyla politine ir kultūrine problema suvaldyti privatumo nykima ir politiškai prisitaikyti prie nauju ǐšǔkiu.

Reikšminiai žodžiai: skaidrumas; privatumas; viešoji erdvė; kaukè.

Viešosios erdvės tyrimuose dažniausias akcentas yra pačios viešosios erdvès funkcionavimas ir jos reikšmè politikos lauko transformacijoms. Tradiciškai mes atsiremiame i Jurgeno Habermaso viešosios erdvés transformacijos teoriją, detaliai aprašytą jos kitimą: „Būtent jis ịtikinamai 
parode், kaip monarchistinė, feodalinė visuomenè, neskyrusi valstybės ir visuomenès, viešojo ir privataus gyvenimo, kurios politika reiškèsi statuso ir galios demonstravimu, palaipsniui dèl naujos liberalios konstitucinès tvarkos virsta visai kitokia, skyrusia viešą nuo privataus ir dèl to suformavusia viešąją erdvę, kurioje vyko kritiniai debatai, skirti viešajai nuomonei formuoti“" ${ }^{\text {“1 }}$ Tačiau dabartinè technologiškai iš esmès pakitusi situacija veda prie naujo poreikio apibendrinti igytą patirtị ir susitelkti ties modernių viešosios erdvès teorijų analize. Privatumas šiuose tyrimuose potencialiai tampa vienu iš esminių, vertinant ir klasifikuojant kintančius visuomenès ir politikos santykius. Vienu iš ryškiausių tokių tyrimų galima ịvardyti Ri-

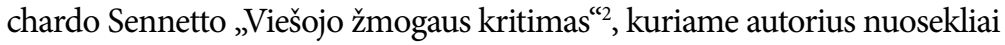
atskleidžia viešųų santykių raidą modernioje visuomenëje ir parodo, kaip privatumas su kiekvienu socialiniu politiniu visuomenių pokyčiu igyja naujų reiškimosi galimybių ir praranda intymumo galimybes.

\section{1.}

Daugelis tyrèjų stebi viešosios erdvės degradavimo simptomus kaip kolektyvinio nedalyvavimo ar abejingumo viešumui reiškimąsi. Tačiau viešoji erdvė gali būti traktuojama ne tik kaip tarpininkavimo terpè tarp valdžios ir visuomenès, bet ir kaip valdžios ir visuomenès tam tikrų santykių institucionalizavimo laukas, kuriame išbandomi ir pritaikomi nauji politinio poveikio ir galių panaudojimo būdai. Mes privalome užduoti sau klausimą, kaip kinta viešoji erdvè ir kaip tai veikia privatumo kultūrą.

Dažniausia frazè, išgirstama šiandien, kai kalbama apie skaidrumo ir privatumo problematiką, yra: privačios asmens erdvés neliečiamumui iškilo grèsme. Viešumo, skaidrumo ir su tuo susietų opozicinių intymumo ir privatumo sąvokų atsiradimas politinès terminijos arsenale nèra tik atsitiktinis artefaktas ar trumpalaikis mados aspektas. Šiandien, kai politikos procesai ypač intensyviai aptarinejjami viešosios sferos erdvëje, esame priversti kons-

Marcinkevičiūtė, R. Nuo Habermaso iki Valinsko: viešosios erdvès privatėjimas. Akiračiai. 2009, Nr. 2-3, p. 1.

2 Sennett, R. The Fall of Public Man. N.Y.-London, Norton \& Co, 1992. 
tatuoti, kad politikos procedūros igyja naujų ypatumų, kurie gali tuo pačiu metu būti tapatinami ir su demokratijos augimu, ir su jos nykimu.

Viena vertus, viešumo ir skaidrumo sąlygų didejjimas politiniame gyvenime tarsi sukuria terpę augti tiesioginei demokratijai, nes skaidrumas suponuoja ne tik politikos veikejjų atsivèrimą visuomenei, bet ir visuomenès aktyvumą kontroliuojant visus politinio lauko dalyvius. Taigi politinių sprendimų priemimo, aptarimų ir derybų proceso potencialiais dalyviais skaidrios ir atviros visuomenès sąlygomis tampa toks piliečių kiekis, koks yra pasirengęs tokiai politinio proceso stebèsenai.

Kita vertus, valstybès saugumas, padidejus terorizmo galimybei, ypač po 2001 metų teroristinio išpuolio Jungtinèse Amerikos Valstijose, tampa susietas su didesniu visuomenės skaidrumo poreikiu. Vis dažnėjantys teroro atvejai, nusikaltimai, palyginti lengva galimybè pasigaminti priemones teroristiniam aktui verčia visuomenę sukurti ir sustiprinti ne tik savigynos mechanizmus, bet ir atrasti tokius prevencijos instrumentus, kurie leistų sužinoti, pamatyti ar nuspèti galimą nusikaltimą iš anksto. Čia skaidrumo sąlyga iš gynybinès, karinès pereina ị politinę ir palaipsniui tampa ne tik technine politikos problema, bet ir ta politinio dalyvavimo galimybe, kur visi gali igyvendinti savo pilietinę pareigą ir kur politika igyja naujų politinių procesų bei veikejuc matomumo ir atvirumo sąlygų.

2001 metais priimtas antiteroristinis įstatymas (Patriotinis aktas) ${ }^{3}$ JAV sukūrẻ situaciją, kada valstybė igijo išskirtinai didelių galimybių ịsiterpti ị privatų asmens gyvenimą. Piliečiai gana savanoriškai sutiko atsisakyti daugelio jų privatumą saugojusių teisinių normų. Imta konstatuoti, kad visuomenè šitaip artëja prie savo privataus būvio galimybių apribojimo. Juolab kad beveik šimtmeti egzistavusi Samuelio Warreno ir Louiso Brandeiso juridiné formule $\dot{e}^{4}$, reikalaujanti palikti asmenị ramybejje ir reiškusi privačios ir viešosios erdvès bei interesų atskyrimą, po 2001 metų Patriotinio akto pavirto atskiru, ginčytinu teisiniu kazusu, leidžiančiu valstybei peržengti

Žr. prieigą per internetą: $<$ http://www.fincen.gov/statutes_regs/patriot/>.

4 Žr. Warren, S., Brandeis, L. The Right to Privacy. 4 Harvard Law Review. 1890, p. 193-220. 
privatumo ribas ir kontroliuoti visuomenę net tada, kai privatumo poreikis yra akivaizdus.

Šis požiūrio i privatumą ir naujo skaidrumo formavimą pokytis turi silpnujuc vietų. Čia formuojasi santykis, kada valdžia tampa suinteresuota vienpusiu skaidrumu: piliečiai turètų būti skaidrūs prieš valdžią, o valdžia - ne. Formuojasi, anot Zygmunto Baumano, poliarizuotas galios santykis: „Erdvès aiškumas, jos skaidrumas virto vienu svarbiausių laimikių moderniai valstybei kovojant dèl valdžios suverenumo. Norẻdama laimèti juridinę socialinès sąveikos ir lojalumo kontrolę, valstybė turèjo užvaldyti skaidrumą tos aplinkos, kurioje priversti veikti tos sąveikos dalyviai. " ${ }^{\text {" Toks }}$ „skaidrumas“ politiškai reikalingas, nes leidžia suskaičiuoti mokesčius, kontroliuoti politines nuotaikas, socialinius-politinius visuomenès judesius. Taigi, remiantis Z. Baumanu, pokyčiai leidžia „padaryti pasauli skai-

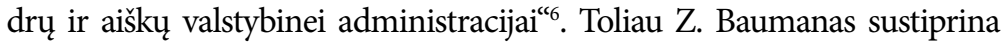
ižvalgas teiginiu, kad „tikslas buvo sąmoningai manipuliuoti ir apgalvotai kaitalioti erdvės skaidrumą kaip socialinius santykius, o galiausiai - kaip

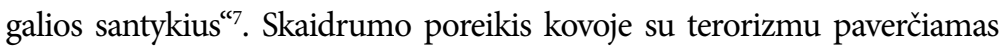
valdžios sustiprinimo mechanizmu. Tačiau toks požiūris sukuria labai neigiamas, antidemokratines tendencijas, kurios vadovaujantis dar platoniška samprotavimo logika nulemia tironijos galimybes. Hannah Arendt pabrèžè bruožus, „kurie mums taip ịtikinamai parodo tironišką Platono valstybès pobūdị - beveik visiškas privatumo pašalinimas ir politinių organų bei institutų visagalybéc8.

Intensyviai kuriamas ir auginamas stereotipas, kad dẻl saugumo reikalinga atsisakyti tam tikrų privatumo sąlygų. Kitais žodžiais tariant - neva privatumą reikia susiaurinti. Tačiau ar visada mes galime teigti, kad privatumas ir skaidrumas yra opozicinès kategorijos, kurios natūraliai privalo viena kitą neigti? Dar daugiau, esu vienas iš tų retų abejojančių, kurie mano,

\footnotetext{
Baumanas, Z. Globalizacija: pasekmès žmogui. Vilnius: Apostrofa, 2007, p. 51.

Ten pat, p. 55.

Ten pat, p. 57.

8 Žr. Arendt, H. Tarp praeities ir dabarties. Vilnius: Aidai, 1995, p. 315.
} 
kad šios kategorijos yra iš skirtingų lygmenų ir jų lygini ar priešinti negalima, tiesiog neįmanoma. Tačiau viskas apibendrinama iki teiginio - arba laisvė (privatumas), arba saugumas (skaidrumas), kur saugumas neišvengiamai lemia laisvių apribojimą. $\mathrm{Na}$, o privatumas natūraliai priskiriamas laisvių grupei'.

\section{2.}

Šiandien galime būti tikri, kad mūsų buvimas viešosiose erdvèse yra kontroliuojamas daugelio tarnybų ir tas kontrolès mechanizmas tik didès. Pavyzdžiu gali būti Didžiosios Britanijos situacija: „Niekur nèra tiek daug stebëjimo kamerų viešose vietose, kaip Jungtinëje Karalystëje. 2002 m. duomenimis - daugiau nei $5 \mathrm{mln}$., įskaitant šimtus ir tūkstančius stebejjimo kamerų, kurias kontroliuoja net ne policija, o savivaldybès ir privačios i̊staigos. Pagrindiniuose šalies keliuose veikia Automatinè automobilių registracijos numerių atpažinimo sistema, kuri fiksuoja absoliučiai visus šiais keliais važiuojančius automobilius (maždaug 8-10 mln. per dieną). Teisèsaugos struktūros aktyviai naudoja ịvairius pasiklausymo įrenginius, o kai kuriose grafystėse policija jau kelerius metus naudoja nedidukus, 1,5 $\mathrm{kg}$ sveriančius, skraidančius stebejjimo robotus, apie kuriuos daugumos ES šalių policininkai kol kas tik sapnuoja. ${ }^{10}$ Didejjant privataus asmens skaidrumui (galimybei ji matyti ir kontroliuoti) kyla abejonių, ar įmanoma bus kontroliuoti skaidrumą formuojančius procesus, skaidrumą užtikrinančias sistemas. Tai yra šios sistemos pačios gali igyti didelį „privatumo“, „nepastebimumo“ statusą ir terpę, kur valdžios padaryti sprendimai, projektai, planai nebus apribojami atskiros institucijos ar visuomenès kontrolès, procesų matymo instrumentais.

Radikaliai (tačiau, manau, kad radikalumą čia galime pakeisti ir tra-

9 Ryškus tokios logikos atspindys yra Jeffrey'io Roseno knygoje: Rosen, J. The Naked Crowd: Reclaiming Security and Freedom in an Anxious Age. Random House, 2004, p. 272.

${ }^{10}$ Žr. prieigą per internetą: <http://www.balsas.lt/naujiena/378654/didieji-broliaivalstybiniai-ir-privatus/rubrika:naujienos-lietuva-komentaraiiranalize>. 
diciškumo terminu) ị situaciją žvelgiantys teoretikai mąsto tiesmukiškai: Charlesas J. Sykesas teigia, kad technologinè revoliucija faktiškai atèmė iš žmogaus teisę i privatumą ir su kiekviena diena ši situacija tik blogès ${ }^{11}$. Regas Whitakeris savo knygoje $\mathrm{e}^{12}$ problemą dramatizuoja maksimaliai - visko priežastis yra totalinės kontrolès metodai, kuriuos priima valstybės: identifikacijos sistemos, biometrija, stebejjimas, informacijos ribojimai ir kt. Šiuo atveju privatumo nagrinejimas reikalauja išsiaiškinti, kaip yra traktuojamas šis terminas. Dažniausi šio termino aiškinimai yra sietini su tradiciniais teisiniais privatumo reikalavimais būti paliktam ramybeje ${ }^{13}$. Robertas Ellisas Smithas ${ }^{14}$ savo ruožtu privatumą traktuoja kaip kiekvieno iš mūsų siekį turèti tam tikrą fizinę erdvę, kurioje mes būtume laisvi nuo ịsikišimo iš išorès. Anot Edwardo Blousteino ${ }^{15}$, privatumas tèra sudedamoji žmogaus asmenybès dalis. Privatumas suponuoja asmeninio gyvenimo, laisvès, savigarbos ir vertybių egzistavimą be kitų siekio jas pasisavinti.

Kova už teises, kaip antai už teisę i darbą, balsavimo teisę, moterų teises, kalinių, homoseksualų, gyvūnų ir kt., išties yra ilga, rutininė, vykdoma pagal seną socialinio santykio suvokimą, kai siekiama išspręsti visuomenès santykių skaidrumo problemą. Atvirai nèra kalbama apie skaidrumą, bet kova dèl teisių galutine prasme yra kova už laisvą saviraišką, ribų, draudimų ir paslapčių jei ne panaikinimą, tai bent jau jų galimybių susiaurinimą. Bet tai ir yra ekstensyvus, vadinasi, ilgas ir apsunkintas kelias ị skaidrumą. Taigi visos žmogaus teisès, vadovaujantis šia logika, yra tik privatumo for$\operatorname{mos}^{16}$.

${ }_{11}$ Žr. Sykes, Ch.J. The End of Privacy: The Attack on Personal Rights at Home, at Work, On-Line, and in Court. St. Martin's Press, 1999, p. 304.

${ }^{12}$ Žr. Whitaker, R. The End of Privacy: How Total Surveillance Is Becoming a Reality. New Press, 2000, p. 195.

${ }_{13}$ Žr. Warren, S., Brandeis, L. The Right to Privacy. 4 Harvard Law Review. 1890, p. 193-220.

${ }_{14}$ Žr. Smith, R.E. Ben Franklin's WebSite 6. Sheridan Books, 2000.

${ }^{15}$ Žr. Bloustein, E. Privacy as an Aspect of Human Dignity. 39 New York University Law Review. 1964, p. 971.

${ }^{16}$ Žr. Volio, F. Legal personality, privacy and the family. In Henkin (ed). The International Bill of Rights. Columbia University Press, 1981. 
$\mathrm{O}$ ar mūsų vidinio pasaulio sprendiniai, emocijos, reakcijos ir impulsai išties tèra mūsų nuosavybe ir mes turime teisę ginti juos nuo kitų? Tada kiti turi teisę reikalauti, kad mūsų vidinio pasaulio sprendiniai neišeitų $i$ išorę, nes kada šie kontaktuoja su kitų sprendiniais, su išoriniu pasauliu sociumu, mes tampame kolektyviais ir mūsų privatumas neišvengiamai paliekamas nuošalyje. Net visa tai, ką aš galvoju, yra mano kolektyvinio, socialaus gyvenimo pasekmè. Asmuo be sociumo neturi pilno ir išlavinto savo vidinio pasaulio, tai „socialinis mauglis“, kurio veiksmai ir reakcijos yra asocialūs tiek, kiek jis nèra ịsitraukęs ị kurị nors sociumą. Taigi privatus pasaulis tera pasisavinta kolektyvumo patirtis.

Ruth Gavison ${ }^{17}$ mano, kad privatumą sudaro trys elementai: slaptumas, anonimiškumas ir vienatvè. Tai būsenos, kurios gali būti prarastos tiek paties asmens noru, tiek ir ịsikišus iš išorès. Šiuo atveju tradiciškai suprantama privatumo sąvoka tampa abejotina, jei mes ir toliau ją eksploatuosime juridinių kategorijų lauke. Dabar privatumo išsaugojimo lygmuo yra ne tiek teisinis tam tikrų gyvenimo sferų atribojimas nuo viešumo (praktiškai to nebeịmanoma kontroliuoti), kiek žmogaus gebèjimas išsaugoti savo tapatybę. Konkrečiau kalbant - gebejjimas būti tolygiu realybei ar tam tikros aplinkos laukui, kuris apibrèžiamas kaip realiai asmens pojūčiams ir suvokimui tinkamas laukas.

Egzistuoja aibẻ loginių, teisinių, politinių, psichologinių, filosofinių argumentų, kuriais bandoma parodyti, kad žmogui būtina jaustis saugiam (saugumo jausmas natūraliai siejamas su jo privatumo išsaugojimu - privatumas be išlygų siejamas su saugumu, saugumo sąlyga, pagrindu), bet privatumo išsaugojimas lemia ir socialinio ryšio silpninimą, kolektyvinị buvimą. Taigi tampa aišku, kad saugus ne tas, kuris yra glaudžiai susietas su didesniu ar mažesniu sociumu, bet tas, kuris įtvirtina, garantuoja sau privatumą, t. y. atsiskyrimą nuo sociumo.

${ }_{17}$ Žr. Gavison, R. Privacy and the Limits of Law. 89 Yale Law Journal. 1980, p. 421, 428. 


\section{3.}

Vis delto pripažistama, kad valstybė (sociumas) turi numatyti privataus intereso/asmens siekius ir juos apriboti, jei jie grèstų visuomenei. Taigi visuomenè tam tikrame lygmenyje suvokia privatumo keliamą pavojų ir supranta privataus asmens skaidrumo naudą sociumui. Sociumo interesas ivardijamas kaip viešasis interesas. Tiesą sakant, tokios viešumo ir privatumo sąlygos buvo suformuluotos dar senovès Romoje. Domicijus Ulpianas (170-223) - vienas ryškiausių Romos juristų, yra suformulavęs taisyklę, kuri šiandien jau yra daugelio priimama kaip natūrali ir privaloma norma: ad statum respublicae (viešumas sietinas su valstybe) ad singulorum utilitatem (privatumas sietinas su atskirų asmenų nauda) ${ }^{18}$.

Terminas asmuo etimologiškai siejamas su graikų kalbos žodžiu proson, o jo lotyniškas atitikmuo yra persona, kuris reiškia aktoriaus kaukę. O terminas individas, individualumas graiku kalboje siejamas su terminu atom ar lotynišku individuum, reiškiančiais nedalomą. Antikoje asmuo (kaukè) - tai vaidmuo, kurị kiekvienas vaidina viešojoje erdveje, t. y. respublica. Graikams kaukè - tai atsiskleidžiančio veido esmè, riba, įkelianti žmogų i visuomenę, socialiai tipizuojanti. Kaukè šitaip tampa žmogaus veidu. Būti privačiu asmeniu istoriškai reiškia būti žmogumi be kaukès. Senovės Graikijoje privatus, atskiras asmuo reiškè idiotą. Tai kilo iš bendruomeninių santykių viršenybès. Senovès Graikijos polių demokratijos esmejje glūdi bendruomenès ịstatymų diktatas, kur privatus interesas neišvengiamai laužo bendrumą ir natūraliai daro siekiantị gyventi atskirai, privačiai labiau pažeidžiamą, taigi rizikuojantị savo ir savo šeimos gerove ir gyvybe.

Krikščionybès laikais privatumo ir viešumo riba perkeliama žmogui tarsi skyrimas tarp vidinio ir išorinio žmogaus. Renesanso laikais viešas gyvenimas pirmiausia buvo suvokiamas laisvo kalbẻjimo raiška. Neturèdamas gražbylystès gebėjimų, žmogus pasmerktas nebūti viešojoje erdvėje: retorika formavo socialumą ir statusą.

Nuo XVII-XVIII amžiaus tai, kas asmeniška, privatu, asocijavosi su

18 Publicum ius est quod ad statum rei Romanae spectat, ius privatum est quod ad singulorum utilitatem (lot.). 
nuosavybe, su jo egoistiniu interesu, kylančiu iš gamtos. Privatumas čia savotiškai sudaiktina žmogų - neturintị nuosavybės, nesugebantị turèti savo privataus gyvenimo pagrindo. Tai sukèlè norą permąstyti asmenybės ir jo privatumo santykį. Vokiečių klasikinè filosofija apibūdina asmenybès savybes kaip laisvę ir savigarbą, išskiriančias ji iš likusio pasaulio. Asmenybė tampa ne sociali, o dvasinè žmogaus reikšmè. Privatumo kaip vertybès problema susiformavo kartu su nuosavybès fenomenu. Ši privatumo ir skaidrumo dichotomija sprendžiama svarstant nuosavybès klausimą - tai, kas priklauso man, yra privatu, o tai, kas yra visų nuosavybè, reikalauja skaidrumo; taigi mano asmeninio gyvenimo priklausomumas man yra mano privatumo/skaidrumo prieš kitus sąlyga. Tačiau, sutelkdami problemą i nuosavybės diskursą, mes ją supaprastintumėme ir negalètume paaiškinti neekonominių privatumo/skaidrumo aspektų šiandienos realybejje. Juolab visi samprotavimai, kurie yra sietini su skaidrumo gynimu, kyla iš abejonès dèl jo igyvendinimo: kalbama apie pavojų privatumui arba apie panaudojimą blogiems tikslams esant skaidrumo sąlygoms. Beveik visada yra kalbama apie skaidrumo teisinį-funkcinį reikalingumą, t. y. problema suvedama ị formalų skaidrumo pilietinejje visuomenèje lygmenị. Tačiau iš esmès argumentai tarsi nukreipiami į abstrakčias individo privataus gyvenimo gynimo pozicijas. Taigi skaidrumas ginamas abstrakčiai, o privatumas - konkrečiai.

Dažnai privatumo argumentai tèra psichologinès reakcijos ị viešumoje kylančius pavojus. Privatumas, baimè ir savisauga yra susiję. Tai, kas nekelia realios baimès, nesukelia privatumo ir intymumo išsaugojimo reakcijų; o tai, kas gali būti pavojinga, sustiprina intymumo ir privatumo poreikį. Taigi privatumas turi baimés ištakas - socializuota reakcija i pavojaus galimybę.

Egzistuoja skaidrumo ir privatumo santykio supaprastinimo kryptis, atsiskleidžianti per vadinamajji „išorès žmogaus“ fenomeną, kai asmenys siekia demonstratyviai rodyti savo gyvenimą, pozuoti, vaidinti kitiems privatumą. Iš tiesų tai nėra nei privatumas, nei skaidrumas, tai - kaukè, specifinè savo privatumo gynimo forma ir instrumentas. Toks postmodernus skaidrumas tèra gebejimas būti nematomu viešumoje. Taigi kalbėti galime ne apie realų skaidrumą ir privatumą, bet apie tai, kad iš esmès visiems 
prieinamas, eksponuojamas, deklaruojamas privatumas leidžia likti nematomu, išsaugoti savo privatumą. Čia tampa aktuali problema ne tik tikimybė prarasti realų privatumą, bet ir naujų nuostatų, įsitikinimų atsiradimas, kad privatumas yra kažkas kita, kad tradiciškai suvokiamas privatumas yra neišvengiamai pažeidžiamas. Skaidrumo igyvendinimas leidžia sumažinti mūsų vaidinamų socialinių vaidmenų ịtaką asmenybiniams interesams, taip mažindamas vidinius prieštaravimus tarp to, kaip turètų būti, ir to, kaip gali ir nori veikti konkretus asmuo. Socialiniai vaidmenys verčia mus elgtis ne taip, kaip to reikalauja giluminiai asmenybès interesai, tačiau taip, kaip to reikalauja sociumas, tradicijos, igūdžiai, todèl „daugelis mūsų esame priversti kasdien vaidinti tam tikrus socialinius vaidmenis, kurių scenarijuose dažniausiai nėra vietos nuoširdžiam atviravimui““19. Tenka pratintis prie situacijos, kurią gana taikliai apibūdino Seimo narys Paulius Saudargas: „Atsirandant vis naujoms galimybėms kiekvienam keistis ir dalintis informacija, kartu ir asmenine, kiekvieno iš mūsų (nebūtinai viešo asmens) ribos tarp viešo ir privataus gyvenimo vis labiau trinamos ${ }^{“ 20}$.

\section{Išvados}

Tradicijų rutina, ịsigalèjęs privatumo ir skaidrumo santykio supratimas, dominuojantis šimtmečius, neleidžia peržengti leistino supratimo ir nesuteikia galimybès priimti skaidrumą ne tik kaip fizikinị ar socialinị reiškinį, bet ir kaip naują vertybinį-moralinį modalumą. Skaidrumas, maksimaliai realizuotas visuomenejje, žlugdo jos tradicinị socialumą - kaip mes ji suvokiame dabar. Esant visiškam santykių ir veiksmų skaidrumui kinta viskas - socialumas, sentimentalumas, moralumas, baimès, seksualumas. Neišvengiamas prasmių ir vertybių perkainojimas, ịprasto biologinio, psichologinio ir socialinio ritmo suardymas - tai ypač matyti politikos lauke. Tenka pripažinti, kad politikoje skaidrumas tampa ne tik diskusijų ir kal-

${ }_{19}$ Kairys, S. Duokite man mano tiesą. Atgimimas. 2008, rugsejo 6 - spalio 2, p. 7.

20 Žr. prieigą per internetą: <http://pilietis.delfi.lt/voxpopuli/facebookkarta.d?id=37099827>. 
tinimų sfera, bet ir realia politinès veiklos scena, kur vyksta atviras savęs rodymas ir igyvendinama visų galimybė matyti visus partijų ir jų narių veiklos aspektus. Skaidrumas politikoje dabar reiškiasi kaip subtiliai kuriama atvirumo visuomenei širma, reikalinga situacijose, kai nepasitikejjimo ir itarumo atmosfera yra didelè. Tai tampa ir argumentu per rinkimus. Net kalbëimas apie skaidruma tampa rinkimu patrauklumo sąlyga. Ir vietoj senos privatumo sampratos, sukonstruotos asmeninio gyvenimo paslapties pagrindu, metas pratintis prie naujos - valstybè ir specializuotos imonès apie mus potencialiai žino viską, nors nesiruošia kam nors apie tai sakyti.

Privatumas neturètų būti siejamas su anonimiškumu; jị vertètų susieti su valstybės ir verslo garantija saugoti privačias komunikacijas ir finansinę informaciją. Taigi kuo didesnis skaidrumas visuomenès gyvenime, tuo didesnè tikimybė, kad paslaptis taps dar subtilesnè ir mažiau pastebima. Ji užims nepaslapties erdvę, taip prisitaikydama prie skaidrumo sąlygų ir sukurdama metaprivatumą. Dabar politikoje sąlyga būti neskaidriu suponuoja mintị - būti pavojingu. Todèl visų stebejjimas ir žinojimas apie tai tampa politine būtinybe. Tačiau būti stebimam, būti matomam ir žinoti, jausti ar numatyti, kad esi matomas ir stebimas, yra ne tas pats.

Mes jau esame tame lygmenyje, kada galime sakyti, kad privalome manyti, jog esame matomi ir galime būti stebimi. Šiandien žinoti, kad esi stebimas, yra ịprasta, nors dar nèra ịprasta jausti, kad esi stebimas išskirtinai, nèra ịprasta žinoti, kad esant galimybei gali tapti stebinčiuoju. Viešumas absoliutus, privatumas - santykinis.

Taigi šiuolaikinė visuomenè, įskaitant politiką, išgyvena sudètingas vertybinių pokyčių procedūras, kur skaidrumo/privatumo opozicija gali nulemti daugelį ateities socialinių ir politinių prioritetų. Skaidrumo išplitimas sukuria terpę naujam moralaus elgesio suvokimui. Asmeninio gyvenimo trūkumas čia jau gali reikšti asmenybès trūkumą ar fragmentinị asmenybès būvị. Juk mano privačia erdve tampa ta vieta ar būsena, kur aš esu pats su savimi. Vadinasi, privati sfera yra ten, kur reiškiasi mano dvasiškumas, dialogas su savimi, o viešoji sfera - ten, kur reiškiasi mano socialumas. Tačiau ši riba yra nepastovi. 


\section{Literatūros sąrašas}

Arendt, H. Tarp praeities ir dabarties. Vilnius: Aidai, 1995.

Baumanas, Z. Globalizacija: pasekmès žmogui. Vilnius: Apostrofa, 2007.

Sykes, Ch.J. The End of Privacy: The Attack on Personal Rights at Home, at Work, On-Line, and in Court. St. Martins Press, 1999.

Bloustein, E. Privacy as an Aspect of Human Dignity. 39 New York University Law Review. 1964, p. 971.

Volio, F. Legal personality, privacy and the family. In Henkin (ed). The International Bill of Rights. Columbia University Press, 1981.

Whitaker, R. The End of Privacy: How Total Surveillance Is Becoming a Reality. New Press, 2000.

Smith, R.E. Ben Franklin's WebSite 6. Sheridan Books, 2000.

Rosen, J. The Naked Crowd: Reclaiming Security and Freedom in an Anxious Age. Random House, 2004.

Gavison, R. Privacy and the Limits of Law. 89 Yale Law Journal. 1980, p. $421,428$.

Sennett, R. The Fall of Public Man. N.Y.-London, Norton \& Co, 1992.

Warren, S., Brandeis, L. The Right to Privacy. 4 Harvard Law Review. 1890, p. 193-220.

„Akiračiai“
„Atgimimas“
Balsas.lt
Delfi.lt
fincen.gov/statutes_regs/patriot/ 


\section{TRANSPARENCY AND PRIVACY BECOMING AN IMPORTANT POLICY ISSUE}

\section{LAURAS BIELINIS}

\section{Summary}

Keywords: Transparency; Privacy; Public Space; Mask.

The article deals with the terms and conditions of transparency/privacy in today's society. The present creates such conditions determined both by the radical political events (terrorist acts) and by new technological possibilities, when the field of privacy is narrowing and the personal publicity is becoming an inevitable and necessary condition. The article identifies a number of problems, offers new and yet unknown areas of policy and social life associated with an increase in transparency and privacy transformations. In the current situation, the public faces a political and cultural issue of coping with the loss of privacy and politically adapting to new challenges.

Iteikta 2012 m. spalio $29 \mathrm{~d}$. 